This item was submitted to Loughborough's Research Repository by the author.

Items in Figshare are protected by copyright, with all rights reserved, unless otherwise indicated.

\title{
Communism and the meaning of social memory: towards a critical-
} interpretive approach

\section{PLEASE CITE THE PUBLISHED VERSION}

http://dx.doi.org/10.1007/s12124-012-9207-x

\section{PUBLISHER}

(c) Springer Verlag

VERSION

AM (Accepted Manuscript)

LICENCE

CC BY-NC-ND 4.0

\section{REPOSITORY RECORD}

Tileaga, Cristian. 2019. "Communism and the Meaning of Social Memory: Towards a Critical-interpretive Approach". figshare. https://hdl.handle.net/2134/11601. 
This item was submitted to Loughborough's Institutional Repository (https://dspace.lboro.ac.uk/) by the author and is made available under the following Creative Commons Licence conditions.

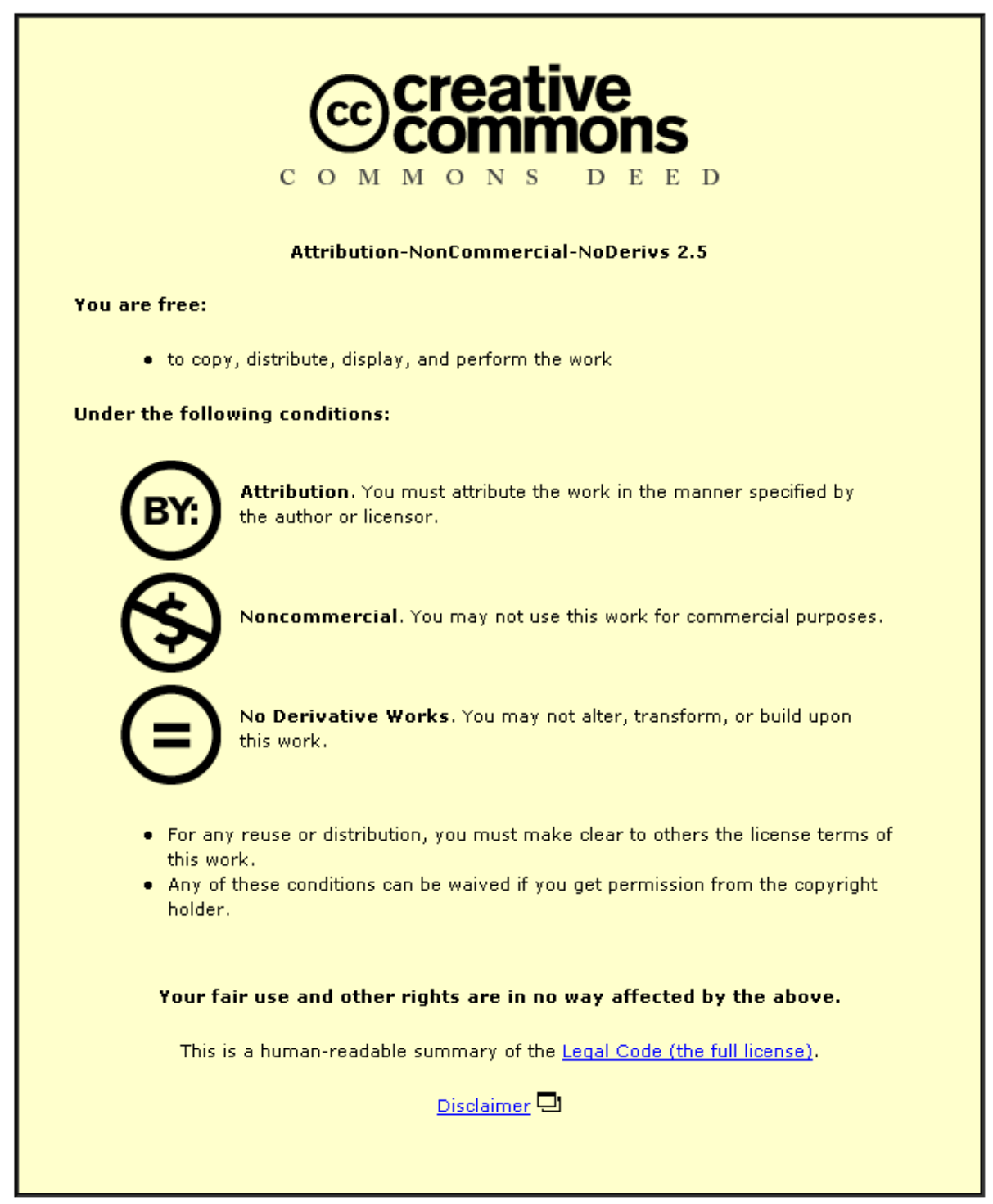

For the full text of this licence, please go to: http://creativecommons.org/licenses/by-nc-nd/2.5/ 


\title{
Communism and the meaning of social
} memory: towards a critical-interpretive approach

\author{
Cristian Tileagă \\ Discourse and Rhetoric Group \\ Department of Social Sciences \\ Loughborough University \\ Loughborough \\ UK
}


Abstract

Using a case study of representations of communism in Romania, the paper offers a sketch of a critical-interpretive approach for exploring and engaging with the social memory of communism. When one considers the various contemporary appraisals, responses to and positions towards the communist period one identifies and one is obliged to deal with a series of personal and collective moral/political quandaries. In their attempt to bring about historical justice, political elites create a world that conforms more to their needs and desires than to the diversity of meanings of communism, experiences and dilemmas of lay people. This paper argues that one needs to study formal aspects of social memory as well as "lived", often conflicting, attitudinal and mnemonic stances and interpretive frameworks. One needs to strive to find the meaning of the social memory of communism in the sometimes contradictory, paradoxical attitudes and meanings that members of society communicate, endorse and debate. Many of the ethical quandaries and dilemmas of collective memory and recent history can be better understood by describing the discursive and sociocultural processes of meaning-making and meaning-interpretation carried out by members of a polity.

Keywords: communism, nostalgia, Romania, critical-interpretive approach, social memory, 'lived' ideology 
Inserting a meaning occurs constantly ... while every existing thing calls for something, and it is not enough to say simply: it is ... Past events also call for

a meaning, as it is difficult to stop at one word, simply saying they were

(Czeslaw Milosz).

\section{INTRODUCTION}

Using a case study of representations of communism in Romania, the paper offers a sketch of a critical-interpretive approach for exploring and engaging with the social memory of communism. In this context, "criticalinterpretive" refers to and reflects an eclectic epistemological and theoretical approach to social memory informed by insights from social psychology (Billig et al., 1988; Billig, 1996; Middleton and Brown, 2005, 2007; Tileagă, 2009) and the interpretive sociology of Alfred Schütz (Schütz, 1964, 1967). When one considers the various contemporary appraisals, responses to and positions towards the communist period (both official and vernacular) one notices that they all seem to point towards a personal and collective moral and political quandary first identified by Adorno: "one wants to get free of the past ... one cannot live in its shadow' but the 'past one wishes to evade is still so intensely alive" (1986: 115). I focus here on the condemnation of communism in Romania in the Tismăneanu Report (Tismăneanu et al., 2007; Tismăneanu, 2008) and public positive evaluations of the communist period, what is usually broadly referred to as "nostalgia for communism" (see, inter alia, Velikonja, 2009; Willinger, 2007; Todorova and Gille, 2010; Ekman and Linde, 2005). 
A critical-interpretive approach to social memory suggests that the quandaries, dilemmas, and difficulties of forging (elite and personal) relations to the recent past can actually be explored in their own right (see also Tileagă, 2011, in press, a and b). Social memory cannot be studied outside of the social and cultural contexts in which it originates. What underpins such contexts are language practices, a variety of meaning-making and meaninginterpretation (Schütz, 1967) practices. It is through language practices that both academic experts and lay people give meaning to social memory and construct representations of (troubled) recent history.

A critical-interpretive approach to social memory rests on three basic assumptions. First, one needs to be able to describe the circumstances (e.g., political, sociocultural, discursive) under which social memory becomes a public affair: how does 'memory' actually 'matter' to people (Brown, 2008; Campbell, 2008; Middleton and Brown, 2007). This entails treating social memory as a relational phenomenon and understanding it in terms of the 'interaction of multifarious interests and world views' (Olick, 2007: 187-188). Second, interpretations and understandings of the recent past (particularly, the legacy of communism, individual and national evaluations of the period) are as much a concern of professional academics (historians, political scientists, sociologists of transition) as they are for ordinary people. One needs to be able to chart how personal and societal meanings (in face-to-face and small group interactions to the use of the official (memory) apparatus of nation-states) are created, circulated, and disseminated. The study of social memory in new democracies needs to take seriously into account the 'contestability' (Connolly, 1993) of social and political categories (e.g., 
'revolution', 'communism', 'democracy', etc.). Social and political categories (and attributes attached to them) are sources of dispute and moralizing and they may mean different things to different people. A third assumption that guides my argument is that examining social memory requires the recognition of the tension between "intellectual" and "lived" ideology (Billig et al., 1988). Billig et al. distinguish between "intellectual" ideology as formal (academic), systematic and systematized philosophy and "lived" ideology as common sense and everyday meaning-making and meaning-interpretation practices (see also Millstone, this issue). Social memory does not simply reflect nor expresses "a closed system for talking about the world" but rather "contrary themes, which continually give rise to discussion, argumentation and dilemmas" (Billig et al., 1988: 6). The formulation of an argument, representation, or attitude towards the recent communist past presupposes that counter-arguments, counter-representations or counter-attitudes are not only possible, but are the very make-up of how personal and societal meanings are created, sustained and circulated in society (Billig, 1996).

The paper argues that any attempt to understand debates, ethical quandaries and politics of social memory in eastern Europe should treat memory as social product reflecting the tension and mutual influence of "intellectual" (scientific) and "lived" (common-sense) meanings, "reified" universe of scientific inquiry and scientific knowledge (especially that of historical and political sciences), and the "consensual" universe of lay representations and forms of knowledge (and memory) that produce the content of common sense (cf. Andrews, 2007; Marková, 1997, 2004; Marková et al., 1998; Moscovici, 2007; see also Jovchelovitch, this issue and 
Knights, this issue).

\section{SOCIAL MEMORY AND NATIONAL NARRATIVES}

Nations are "imagined communities" of memory and forgetting (Billig, 1995). There is something called "public" or "national memory", which is not something we just "have" or "own", but rather something we "create" (Andrews, 2003) from the historical "big narratives" of the national group and the "little narratives" of individuals (Rowe et al., 2002): national memory and national narratives are a (contested) terrain where "official culture" and "vernacular culture" meet (Bodnar, 1992). National memories participate in the ongoing, unfinished identity project of the national collective. A variety of public forums such as public commemorations, museums, monuments, truth commissions, and so on, mediate conflict and negotiation in "the social and political sphere ... of 'memory politics' ... and are carried out in the service of providing a usable past that serves some identity project" (Wertsch, 2007: 650). The problem is how one decides, "how a set of events should be emplotted into a storyline?" (Wertsch, 2011: 27). Also, who gets to decide this and in whose interest? (Wertsch and Karumidze, 2009). Existing shared national narratives or "narrative templates" (Wertsch, 2002, 2008) have an important role in shaping collective interpretation and memory.

From post-apartheid South Africa to post-communism in eastern Europe, national narratives around the recent past have mediated both empowering and progressive as well as limiting and conservative representations of recent history, identity projects and political action. 
Narratives around national historical events have not only liberated people from under the sway of oppressive regimes but they have also "unearthed complicated narrative ways of mnemonic reconstruction and construction" (Brockmeier, 2010: 10). Although there is usually a stark emphasis on "narratives" and "narratives templates" as mediators and generative tools of collective/social memory, these represent only one dimension of appraising the social memory of the recent past. There is also a strand of social psychological study of collective memories of socio-political events (cf. Pennebaker et al., 1997) concerned with the role of cognitive, emotional and social factors in individual and collective memory formation. Dialogical (Markova et al., 1998) and discursive/textual (Tileagă, 2009) concerns with collective memory, as well as concerns with identifying the various roles and functions collective representations of history serve (Liu and Hilton, 2005) have added significant insights. Sociologists, but especially historians and political scientists have approached collective memory with a concern of documenting and explaining macro-social political and historical processes of change and transformation. In contrast, anthropologists, ethnographers and some cultural historians have pointed to the moral ambiguities and vagaries of memory that often stem from the idea that the memory of social and historical "realities" can be placed by academics, politicians, ordinary citizens, and so on within different social frameworks and networks of interpretation (Bucur, 2009; Gallinat, 2009). 


\section{UNDERSTANDING (THE LEGACY OF) THE RECENT PAST: THE CONDEMNATION OF COMMUNISM}

Twenty years after 1989 issues of remembering and forgetting are still dominant concerns in post-communist countries in eastern Europe (especially among public intellectuals and politicians). The fall of communism and transition to democracy has put eastern European societies in the position of needing to fashion and give an account of themselves and their recent, often tumultuous transformation. The various manifestations (successes and failures) of a politics of memory in eastern Europe (positions and debates on the nature and function of democracy, justice and reconciliation with the past, trials, amnesties, laws of condemnation, etc.) point to the vagaries and difficulties of a clean and ultimate break with the recent communist past (Stan, 2006; Waśkiewicz, 2010; Galasińska and Galasiński, 2010; Petrescu and Petrescu, 2007; Tismăneanu, 2008, 2010c).

The various attempts at official, normative interpretation of recent history (based on the opening and access of archives of the communist regime, oral testimonies, memoirs of former political prisoners, dissidents, etc.) were setting the frame for political and moral reflection and action around how to take communism into public consciousness, arguably the greatest political, epistemological and ethical challenge of post-communist states. The essence of official attempts at "mastering" and "coming to terms with" the communist past (and also the key difficulty) was to get society "to come to a common mind" (Taylor, 2004: 91), to propose and ratify a moral and political vision of (retrospective) justice around a normative "morality tale"1. The

\footnotetext{
${ }^{1}$ One of the problems for elite discourse (politicians, historians, political scientists) was how to
} 
ultimate aspiration of official attempts at representing recent history was to provide a rational and synthetic, unified, social memory, to generate noncontroversial (historical) knowledge and truth-telling perspectives capable of overriding lay, individual experiences or perspectives. The main (selfassigned) task of the historian or political scientist is to construct a representation of the recent past by uncovering "the facts about the past" and recounting them "as objectively as possible" (Skinner, 2002: 8).

The collective relationship of eastern European societies to their recent history, the struggle with seeking and generating (active and transformative) knowledge of the past has meant engaging, creating and managing (emerging) social representations of values and attitudes towards the recent past. It has also meant asking the question: how does one tell the 'story' of communism? How many stories of communism can one tell?

The role of politicians and professional academics was to ensure that official representations of the communist past set the moral agenda of the present, shape a moral public discourse and sensitize present generations of their responsibilities to the past. The "Tismăneanu Report" (henceforth the 'Report') condemning the crimes and abuses of communism in Romania (1945-1989) was such an attempt (for more details on the structure and scope of the Report (see Tismăneanu, 2007a, 2008); for reactions to the Report, see Ciobanu, 2009; Cesereanu, 2008; Hogea, 2010; Stan, 2007; Ernu et al., 2008). The leading author of the Report was Professor Vladimir Tismăneanu,

get others to participate in a general vision of justice and "moral identity" (Gergen, 2005: 116) within the national community. In order for society to come to a "common mind", the ordinary citizen needs to be first "convinced by the proposed conception of justice before ... consensus can come about" (Habermas, 1995: 122). 
an internationally renowned expert (political scientist and historian) of communism. The Report consists largely of an account of communism's political methods and institutions. It aims to convey the repressive and criminal nature of totalitarian society and give an exhaustive account of communism as self-perpetuating political system. In December 2006, in front of the Romanian Parliament, the Romanian President Traian Băsescu, officially condemns the crimes and abuses of the Communist regime.

The Tismăneanu Report was at pains to construct a practical framework for the inquiry as a matter of public concern. This was achieved through making reference to a broader framework of political reconciliation and transitional justice and as responding to a public concern over public and political responsibility in relation to the past. The public concern and necessity of condemning Communism was legitimated through a combination of repertoires of (knowledge) entitlement ('the right to know'), obligation and moral accountability, and laying the basis for a moral/political public judgment around the relevance and significance of uniquely bound features of Romanian communism: 'illegitimate' and 'criminal' (see 1-3) (for more details on how the Report constitutes a practical framework for the inquiry as a matter of public concern see Tileagă, 2009).

(1) "Condemning communism is today, more than ever, a moral, intellectual, politic, and social duty/obligation. The democratic and pluralist Romanian state can and ought to do it. Also, knowing these dark and saddening pages of 20th century Romanian history is indispensable for the younger generations who have the right to know the world their parents lived in"

(2) "Against the facts presented in this report, it is certain that genocide acts have been committed during 1945-1989, thus the communist regime can be qualified as criminal against its own people" 
(3) "'Taking act of this Report, the President can say with his hand on the heart: the Communist regime in Romania has been illegitimate and criminal"

According to the Report, communism cannot be defined in terms of characteristics that are accidental, but rather in definite and deliberate terms that may provide the support for an explanation of the nature and motivation of the communist totalitarian system. The attributes 'illegitimate' and 'criminal' do more than describe communism, "they place it in a class of objects, thereby suggest with what it is to be judged and compared, and define the perspective from which it will be viewed and evaluated" (Edelman, 1970: 131). By emphasising the criminality and illegitimacy of communism, the Report creates, affirms and legitimates a narrative for an ethics of memory: social remembering transmits responsibilities (Poole, 2008) and is an obligation for the community (Thompson, 2009).

Weighing the legacy of the past ("setting the record straight") is limited to a discrete field of knowledge production and transmission where "opinions are based upon warranted assertions ... judgments are not mere guesswork or loose suppositions" (Schütz, 1964: 122). For instance, the coordinator of the Report, Vladimir Tismăneanu, can write:

"For me, as historian and political scientist, the verdict of such a commission was not needed in order to argue that 'communism has been an aberrant system, criminal, inhuman"'. (Tismăneanu, 2007b) 
The grounds for preferring and subsequently championing a particular way of construing the meaning of communism are given by an academic 'community of agreement' and taken-for-granted knowledge arising from disciplinary/academic adherence. In this context, a description of the nature of the communist authoritarian regime is carrying 'its own interpretation, its own truth' (Friedlander, 1992: 7). Nonetheless, as Todorov suggests,

"the study of history can never totally ignore the values that permeate human existence ... If historians are going to further their understanding, to collect as many facts as possible and formulate the most accurate interpretations, then they must not decide ahead of time what morality they want to see in the end. History comprises very few pages written in black and white only" (2009, p. 89-90).

Although seemingly capturing the essence of communism as political ideology, arguably, the Report does not seem to be directly concerned with "social reality in its full concreteness, that is, as experienced by the social actors themselves in their daily lives" (Schütz, 1975: xxix). There is an inherent tension present in any attempt to constitute a unitary and coherent version of the past. The hallmark of creating and reproducing social memory in the public sphere is represented by a "dogmatic commitment to one - and only one account of the past" (Wertsch, 2002: 125). A process of "canonization" of a unique representation of recent history requires that alternative experiences, perspectives, interpretations are actively suppressed. The political and academic desire is that of accounting "without rest", giving the full and definitive description and assessment of communism. The Report attempts to create an official narrative of communism which in and of itself limits any conceivable counter-accounts or alternative positions. The Report pays less attention to questions which are as important: Can issues of 
retrospective justice really be "fixed for all time" (Teitel, 2000, p. 104)? What the Report seems to underplay is that "setting the record straight" is "a value at all levels of individual and social existence, not just at the level of science or scientific history" (Carr, 2008: 135). The meaning of the social memory of communism within a framework of transitional justice is on one hand determined by the history of past persecution, but also by subjective dimensions of interpretation and struggle between scientific and lay meaningmaking and meaning-interpretation practices.

Beyond the "community of agreement" provided by historical and political science, official national narratives can prove problematic. The adoption of a moralizing voice and factual descriptions does not guarantee that the different social and political actors from across the political spectrum will join this community of agreement. This is because it is usually believed that facts speak for themselves. The description of communism ("illegitimate and criminal") do not speak by themselves. As Jenkins argues, "all facts to be meaningful need embedding in interpretative readings that obviously contain them but which do not simply somehow arise from them" (1991: 33). "Selfsufficient" (LaCapra, 2001) professional research endeavours are most effective in shielding official ideologies and images from the impact, contradictions, and paradoxes of memory and everyday meanings, from alternative ways of deriving and socially approving knowledge of the recent past. They are effective in shielding official representations of recent past from various individual attempts at challenging public "master narratives", official versions of the past (Andrews, 2007). Hannah Arendt expresses this cogently: "the modes of thought and communication that deal with truth ... are 
necessarily domineering; they don't take into account other people's opinions" (Arendt, 1977: 241). An approach based on "anamnestic solidarity" with the suffering of past victims and a perspective on recent history that relies on public moral and rational discourse in the present is sometimes not enough. The process of creating official political narratives usually informs or accompanies political process and supports national identity projects (Olick, 2007). Nonetheless, this is process that can prove entirely insensitive to alternative social meanings and ways of constructing visions of the recent past. Although the Report does offer crucial insights into the nature and motivation of the communist regime, it fails to take fully into account that creating and maintaining (normative) narratives of social memory is essentially an uncompleted intersubjective (dialogical, rhetorical, argumentative) undertaking.

To describe communism as "illegitimate" and "criminal" is both "to describe it and to ascribe a value to it or express a commitment with respect to it" (Connolly, 1993: 22). Every historical event, social formations and social structures transmit "an excess and surplus that might sabotage the historian's carefully chosen criteria of judgment” (Cohen, 2006: 200). Arguably, communism was not just an external ideological order governing or influencing the behaviour of elites and population. Communism was, for most people, "lived reality" (Bucur, 2009; Gallinat, 2009), and essentially "incommunicable" to those who have not lived it (George, 2011). When the professional historian of eastern Europe, or sociologist of transition describes the communist social and political order, he or she is describing a social object that has previously been defined, described, by lay social actors 
(Watson, 2009: 1). It can be argued that the bulk of knowledge adduced to construct representations of communist recent history consist of an interplay, mixture of experiences and insights that originate in a) the immediate experiences of Communism (communicated from one individual to the other); b) the immediate experiences of communism/events of those who have experienced Communism in a 'unique or typical context of relevance' (Schütz, 1964: 132) that is substantially different from that of ordinary individuals (e.g. political prisoners, (former) members of the nomenklatura, (former) members of the Secret Police, and so on); and c) a very specific way of conceiving the experience of the past, one that relies on what Alfred Schütz has termed the epoché peculiar to the scientific attitude (the province of historians and political scientists), which is seen as independent of the previous two. Of course, this typology does not exhaust the innumerable experiences, and modalities of experiencing communism ${ }^{2}$. This is merely a point that relates to the broader issue of what particular aspects of lived experience shape the formulation of what it means to "come to terms with the past". Lived experience, and narratives that support it, have profound consequences for retrospective and prospective worldviews around morality, justice, personhood, etc. It should not come as a surprise that the activation of certain moral and political tensions within a society: 'us' and 'them' (e.g., 'former communists' vs 'democrats'), different political parties and social groups, were

\footnotetext{
2 To this one can add the shared social representations of social and political realities understood as 'cultural spaces' of negotiation of societal meanings (Tateo and lannaccone, 2012) that encapsulate tensions between 'immediate' experiences of communism and experiences triggered by cultural, social and political cues in the present. It could be argued that this distinction (although potentially problematic) works in resonance with another distinction (operated by both researchers and ordinary people) between 'official' and 'unofficial' spheres of experience and social practice - see, for instance, Fitzpatrick's (2000) work on 'everyday Stalinism'. I owe this point to an anonymous reviewer.
} 
(and are still) grounded not only in political interest and power structures, but also in 'lived' experience, and various narratives, standpoints, that arise from it, in the different ways in which communism was actually experienced ${ }^{3}$.

The different ways of conceiving the experience of the past seem to be tied to a notion of communism understood as a "reality" that is already socially constituted and distributed in 'documentary' form (Smith, 1974). There is a "reality" of communism which is prior to the contemporary official version of events; it is a "reality" contained into the records, files, and other forms of systematic collection of "information"' (Smith, 1974: 261) of the regime.

Communism is also a confessionally constituted knowledge incorporated into various types and kinds of witnessing and testimonies, and various others public sources of memory ${ }^{4}$.

\section{POSITIVE PUBLIC PERCEPTIONS AND NOSTALGIA FOR COMMUNISM}

One of the most striking (but perhaps least surprising) aspect of coming to terms with the past in eastern Europe is that the official reckoning with the communist past and the reinforcing anti-totalitarian views has not inevitably contributed to an attachment to democratic values and attitudes and

\footnotetext{
${ }^{3}$ I do not wish to suggest that "lived" experience is all there is. I do not wish to suggest that "everything goes". "Lived" experience is a domain of social life, a unique, peculiar, foundational realm. It is also a social tool for accomplishing very specific personal and social goals. For instance, appeals to "lived" experience support both progressive and retrograde (revisionist) aspects of social memory. The "voice" of the victims is lived experience, as was the work of the Securitate operatives. Memory and experience work as recursive processes that manage the tension between stability of meanings and change, continuity and innovation. ${ }^{4}$ It is not from historians and political scientists that most people get their knowledge of the past, but rather from "lived experience" and manifestations of popular culture: novels, newspapers, magazines, politicians, public personalities, and so on. One tends to underplay the importance of public sources of memory and the role of "memory consumers who use, ignore, or transform" memories and public artefacts "according to their own interests" (Kansteiner, 2002: 180).
} 
to an indivisible consensus around a (moral) national narrative and representation.

"the legacy that usually proves most difficult to handle is not so much institutional as attitudinal. Views of politics change after a dictatorial experience either through aversion or disillusionment. This produces sometimes a withdrawal from politics or in other cases either points of conflict or, on the contrary, a desire for avoiding them ... At a deeper level, mentalities from the authoritarian era may well affect notions or perceptions of 'democracy"' (Pridham, 2000: 49-50).

Various public opinion polls/surveys in eastern Europe reflect the "attitudinal legacy" to which Pridham refers. It is usually expected that, all other things being equal, "within the boundary of the nation, agreement should exist on the moral valuation of the collective memory even if the particular justifications differ" (Fine, 2001: 22; see also Wertsch, 2002). Yet what one notices is a striking and intriguing contemporary phenomenon: positive public evaluations/perceptions of the communist period, what is usually broadly referred to as 'nostalgia for communism' (Ekman and Linde, 2005; Todorova and Gille, 2010; Velikonja, 2009; Willinger, 2007). Positive public perceptions of communism are usually seen as "paradoxical", "bewildering", "mindboggling", "bizarre" and "ambivalent"; these perceptions question and throw into doubt consensual official/elite expectations around a shared moral national valuation of the social memory of communism. Some researchers have gone so far as to suggest that the highly contested nature of memory, issues and intensity of debate around coming to terms with the past (e.g. ‘decommunization'/'lustration', 'reconciliation', ‘condemnation' of communism), the bewildering ambivalence towards the recent past in the public sphere, indicate the presence of a "trauma of collective memory" (Sztompka, 2004: 
183; see also Kattago, 2009 on attempts to construct a unified European memory of trauma). "Traumas of memory" are seen as the effect of polarized public opinion, of society not coming to a "common mind" about issues of national interest. The notion of "trauma" conjures an image of a divided public sphere where agreement cannot be achieved solely through the "public use of reason", where all "citizens" participate, and which lend "moral convictions their objectivity" (Habermas, 1995: 124). Within the context of ambivalence towards communism, "coming to terms with the past" as an individual and group attitude is turned into a social problem, one that requires explanation: How is it that people can regret the communist regime? How can people just ignore its criminal and oppressive legacy? How can one explain "nostalgia for communism"?

Nostalgia has moved from being an accepted and "acceptable catchword for looking back", a "pervasive, bitter-sweet feeling not yet taken too seriously" (Lowenthal, 1989: 18-19) to "topic of embarrassment and a term of abuse" (p. 20; see also Pickering and Keightley, 2006). For Susannah Radstone, for instance, nostalgia is not the outcome of some social process, but rather "point of departure, opening out into ... questions of knowledge and belief, temporal orientations and cultural ... politics that it condenses" $(2010$, p. 189). Nostalgia is both a "generic", explanatory category and a description of a temporal orientation, veiled desire and search for a "simple and stable past as a refuge from the turbulent and chaotic present" (Lowenthal, 1989: 21; see also Boym, 2001).

In eastern Europe, nostalgia (especially in relation to communism) is a term heavily imbued with political and ideological significance. It has been 
argued that "communist nostalgia is ... a multidimensional phenomenon" (Ekman and Linde, 2005, p. 370) and cannot be easily apprehended within a single framework. For some, "nostalgia for communism" is a very serious matter: it risks falsifying the past and threatens a democratic future. It is nonetheless considered "misleading to suggest that ... 'nostalgia' amounts to anti-democratic feeling' (Pridham, 2000: 51). Communist nostalgia "encompasses more than just non-democratic principles" (Ekman and Linde, 2005, p. 371). Nostalgia in general and nostalgia for communism in particular, embodies progressive, regressive, utopian stances, and signals a longing for an idealized past (Pickering and Keightley, 2006).

For some researchers of post-communism, the presence of nostalgia as a social phenomenon is given by the "intriguing" results of "public opinion" polls. Through their emphasis on anonymity and abstractness, surveys and public opinion polls are designed and used as instruments of deriving social and scientific knowledge. From this perspective, nostalgia is "accepted and treated as though it were an objective reality to be discovered by polling or otherwise" (Edelman, 2001: 53). Velikonja (2009) offers some examples of various public surveys conducted in different countries in eastern Europe that show 'nostalgic' stances towards the recent communist/socialist past. In 1999, $50 \%$ of Slovakians considered the former socialist regime to be 'better than current democracy'. In the same year, in Russia, it was found that $85 \%$ of Russians regret communism and Soviet Union's demise. In 2004 the figure fell to $74 \%$. In $2002,56 \%$ of Poles were telling opinion pollsters that life 'was better before'. In 1995 and 2003, 88\% and respectively, 86\% of Slovenians considered life in the former Yugoslavia, as 'good' and 'very good'. More 
recently (2009) $72 \%$ of Hungarians, $62 \%$ of Bulgarians and Ukrainians, $60 \%$ of Romanians, $45 \%$ of Russians, $42 \%$ of Lithuanians and Slovaks, $39 \%$ of Czechs, $35 \%$ of Poles declared they were worse off than during communism. There are different factors that are seen as triggers and explanations of the onset and manifestations of nostalgia for communism in eastern Europe: "passive escapism ... of people who cannot adapt to new conditions", "general discontent", "personal memories of life under communism", a way to "fill up the legitimation deficit of contemporary societies", "resistance strategy of preserving one's personal history and group's identity against the new ideological narratives" (cf. Velikonja, 2009). Ultimately, nostalgia for communism reflects and expresses a "retrospective utopia ... a wish and a hope for the safe world, fair society, true friendships, mutual solidarity, and well-being in general" (Velikonja, 2009: 547-548).

Recent Romanian polls ${ }^{5}$ have identified striking paradoxes of opinion and memory: $44 \%$ of participants declare that communism was "a good idea, but applied wrongly". $45 \%$ consider that they would have had a "better life if it wasn't for the revolution". $52 \%$ believe that the "problem of access to Securitate dossiers is not important". $83 \%$ consider they "have not suffered under communism". Although $50 \%$ believe that "it was better before" December $1989,41 \%$ do consider that the communist regime was "criminal";

\footnotetext{
${ }^{5} \mathrm{~A}$ major opinion poll was conducted by CSOP (in collaboration with The Institute for the Investigation of Communist Crimes and the Memory of Romanian Exile (http://www.crimelecomunismului.ro/en/about_iiccr) under the title 'Attitudes and opinions on the Romanian communist regime'. Data was collected between $22^{\text {nd }}$ October $-1^{\text {st }}$ November 2010. The report is available at http://www.csop.ro/index.php?act=media\&op=view\&id=13 [accessed January 2011]. Two opinion polls were conducted by IRES (the Romanian Institute for Evaluation and Strategy), one under the title 'Romania: Twenty one years since the Revolution' in the period $19^{\text {th }}-21^{\text {st }}$ December 2010 and the other one, 'Romanians and nostalgia for communism' in the period $21^{\text {st }}-23^{\text {rd }}$ July 2010 . Reports are available at www.ires.com.ro [accessed January 2011]
} 
Although more than half of Romanians consider that communism was a repressive regime, only $13 \%$ of them consider they have "suffered" under communism. Although more than half of Romanians consider that access to Securitate files is unimportant, a vast majority think that those who have collaborated with the secret police should not occupy public posts ${ }^{6}$.

A recent Soros foundation study/poll (Bădescu et al., 2010) looking at the civic and political engagement of Romanian teenagers found that $38 \%$ of respondents considered the communist period "better" than the present state of affairs. $72 \%$ of the teenagers that took part in the study declared themselves to be "not satisfied" with the achievements of the current regime in comparison to the communist period, especially in relation to "respect for law". Also, $57 \%$ considered that people had "better lives" in communism. For the authors of the study, the "origins of the positive valorization of communism seem to be located at the level of socio-economic frustrations in the medium in which teenagers grow up, defined narrowly (the family) or broadly (the school, the community)" (Bădescu et al., 2010, p. 65). Political commentators who have lived through the "revolution" of 1989 distinguish between the moral/political views of their generation and that born after 1989, and can write: "our generation speaks a language that is increasingly very difficult to understand by the generations born after 1990" (Tapalagă, 2011). Nostalgia is a tangible phenomenon. It can be detected, for instance, in the words of a Romanian sociology student: "the most regrettable aspect were the well-

\footnotetext{
${ }^{6}$ I will not go here into a critique of the way these opinions polls were constructed, how the questions were designed, their error margins, and so on. Epistemological and methodological issues relating to opinion polls on perceptions of communism and social change require separate analysis that is beyond the scope of this paper. I rely here on reports and interpretations of opinion poll results made freely available to the wider public.
} 
known queues ... yeah, it was bad, but the international debt of Romania was

paid. Now, in contrast to what happens to all of us now, we have increasing

debts and I fear that we could return to how we were twenty or thirty years

ago. This is my worst fear, not how it was then, but what will be ... we

shouldn't repeat the past, the history of communism in a democratic

Romania." (apud Tapalagă, 2011)

In the Romanian context, nostalgia for communism, and the range of contradictory opinions, are considered (and explained as) "a form of inertia", a refusal, fear and "escape from freedom" (Tismǎneanu, 2010a), a "latent complaint" in relation to "present everyday frustrations" (Tismǎneanu, 2010b), a "normal phenomenon" linked to a "crisis of identity of Romanian people" and "dissatisfaction" with the current political class (Dâncu, 2010) ${ }^{7}$. For others, nostalgia for communism, and paradoxical opinions are seen as originating in and explained by a lack of elite management of social memory and a lack of information and individual insight, failings of memory, and deep confusion in ideas, values, perspectives:

'the population lacks a sophisticated understanding of 'suffering' during the communist regime. One needs to explain, in order to make one's own, the criminal nature of dictatorship ... Perceiving yourself as a victim of a totalitarian regime entails a full understanding of the inner workings of the regime ... there is a danger of creating a selective memory of communism, based primarily on personal experience and which disregards the repressive nature of the regime" (lacob, 2010)

Others contend, "it is unconceivable that after half a century of barbarism,

\footnotetext{
${ }^{7}$ There are, of course, a variety of other functions that nostalgia fulfills. The analysis can be taken in the direction of 'symbolic capital' and coping with rapid social change; nostalgia as a reaction to attempts by elites to 'impose' hegemonic representations of the recent past; nostalgia as a specific stage in a 'developmental' sequence of self and (social and historical) context appraisal. It is, perhaps, also very much the case that people can combine both condemnation and nostalgia in their appraisal of the recent past, and such paradoxical amalgamation can be transmitted to the generations that do not share 'immediate' experiences of socialism.
} 
penury, and censorship, people should tell us that they have not suffered under communism".

What "suffering" means is not treated as an everyday concern for social actors, something that may have different meanings, but rather a normative, pre-ordained "reality" of communism linked to the official memory of communism as barbaric and criminal towards its own people. Elite accounts (as opposed to vernacular ones) can be said to show "a desire to rationalize public life" by "placing a set of ambiguities and contestable orientations under the control of a settled system of understandings and priorities" (Connolly, 1993: 213). These accounts point not only to a normative conception of society, politics and morality (a normative representation of the recent past), but also to a conception of the person: empty-headed or muddled-headed, confused, providing an uncertain, unreliable, often misleading (and potentially immoral) account of what is, "in actual fact", the "reality" of communism. Explanations of the broader phenomenon of nostalgia for communism and more specific contradictions of opinion seem to rely on a socially constructed (political and moral) imaginary of communism yet seem to paper over inconsistencies, ambiguities or contradictions (often explaining them away). One could argue that there is a sense in which "opinions regarding controversial issues are always ambiguous ... they are often inconsistent or mutually contradictory ... they are typically so volatile and subject to change with new cues. Only noncontroversial beliefs remain consistent and are not multivalent, but they do not become political issues" (Edelman, 2001: 55). Elite accounts also paper over the multiplicity of social frameworks of memory (Halbwachs, 1992), multiple realities, memories and meanings attached to communism as "lived ideology". Such explanations fail 
to accommodate the idea that ideology comprises contrary themes (Billig et al., 1988) and downplay the notion that "there are myriad means of describing 'what actually happened', multiple stories, each felicitous within its own community of intelligibility" (Gergen, 2005: 117).

More generally, these interpretations seem to downplay the idea that not all members of society "accept the same sector of the world as granted beyond question" (Schütz, 1970: 237). This can obscure the mediated nature of telling stories of communism and the variety of identity constellations and networks of interpretation (Bucur, 2009; Gallinat, 2009). Attitudes and memories towards the recent past are not given or pre-existing and then harvested with the help of opinion polls, but rather multimodal, circulating and circulated by active agents at various levels of social organization through the use of material/cultural tools (e.g. narratives, written records, and so on) (cf. Wertsch, 2007). If one takes seriously the idea that "it is the meaning of our experiences and not the ontological structure of the objects which constitutes reality" (Schütz, 1967: 230), then results of opinion polls (and vernacular accounts) present only apparent paradoxes. Positive public perceptions of communism, and generally, nostalgia for communism, signal a failure of a conception of "coming to terms with the past" where "the citizens mutually convince one another of what is just and unjust by the force of the better argument" (Habermas, 1995: 124). Although the contradictory results can be explained in psychological, sociological and political terms, the heart and nature of these contradictory standpoints is left untouched. Difficulties arise for opinion pollsters and commentators when wanting to attain "objective and verifiable knowledge of a subjective meaning structure" (Schütz, 1967: 36). 


\section{ANALYSIS TERMINABLE ... AND INTERMINABLE}

A critical-interpretive approach proposes a broader epistemological and theoretical foundation for understanding of the social memory of communism. The range of (possible) meanings attached to communism and the political project of "coming to terms with the past" can be broad; the process of understanding can be very complex. One needs to acknowledge that contrary, contradictory, ambivalent standpoints and views are possible. Working with one description, "communism is illegitimate and criminal", it is almost impossible to give justice to the variety of assumptions, individual and group frames of reference, situations and histories that are meaningful beyond any single description (Gergen, 2005). It is social actors themselves, and not contexts beyond them, their own orientations to personal and historical context that provide the social/cultural/political interpretive framework.

The hope of linear, consensual, progressive national narratives (championed and fashioned through official representations of recent communist past) is upset by the unevenness, ambivalence, contradictory nature of individual positioning in relation to the recent communist past. The tension between the two positions engenders a social problem. This social problem is not just a temporary difficulty that a government or other official representative of the nation could resolve, for all time, through better and more comprehensive historical and political science inquiry; it is rather a consequence of an inability to incorporate and work with a perspective on social memory that highlights the "lived" character of ideology, the unfinished 
nature and diversity of perspectives, attitudinal and mnemonic dilemmas and ambiguities. In undertaking to transform "old" vocabularies of repression into "new" vocabularies of democracy and freedom, to put things right and accomplish historical justice one constitutes a world that conforms more to one's needs and desires (those of the historians and politicians) than to the diversity of meanings of communism, experiences and dilemmas of lay people. One needs to study both the formal production and reproduction of communism as political ideology as well as "lived", often conflicting attitudinal and mnemonic stances and interpretive frameworks. This would be a first step towards dispelling the illusion of a linear relationship between accumulation of "positive" knowledge and moral/political transformation at institutional/group/individual level. It would be also a first step toward capturing the essence of socio-political dilemmas and paradoxes of memory and opinion in the public sphere as reflecting the work of social actors that creatively acknowledge, resist, question or transform social and political reality. Dilemmas and paradoxes of social positioning towards the recent communist past pose sometimes (insurmountable) problems for opinion pollsters and historical/political approaches to "coming to terms with the past" that are not ready to take fully into consideration that lay standpoints and meanings on the recent communist past are far from orderly, homogeneous and predictable. Researchers of communism and post-communism need to look beyond public opinion polls to analysing the actual social and argumentative context of forming opinions and viewpoints in relation to communism as socially constituted phenomenon that acquires very different meanings and interpretations for different people. The existence of 
contradictory, ambiguous and paradoxical standpoints towards communism does not point necessarily to a lack (of knowledge or of insight) or forgetfulness, but rather to an essential characteristic of how common sense functions and is reproduced by social actors in society (Billig, 1996; Potter and Wetherell, 1987); it points to the argumentative character of social life where holding opinions is fundamentally a process of argumentation and debate (Billig, 1996).

It is believed that "telling the truth" about the past and making it public will enlighten people and change perceptions. If one can only find the "right" words to describe the past, its nature (essence) will "reveal" itself to everyone. Telling the truth about the past is also an attempt to stifle and "control" returns of "negative currents" (revisionist accounts, nostalgia), to bring the "repressed" oppressive ideology and effects of communism into consciousness, thus banishing the risk (and fear) of repetition (Freud, 1937). In trying to understand both positive and negative aspects of coming to terms with the past in eastern Europe one should perhaps acknowledge that facts of history can be known scientifically, but only through "progressive approximations to a reality that is never completely attained" (Chesneaux, 1978: 45-46). There is no "natural end" to understanding the recent past; there is no ultimate story. There is always the danger that "a historical phenomenon clearly and completely understood and reduced to an intellectual phenomenon, is for him who has understood it dead" (Nietzsche, 1980: 14).

As argued in the Introduction of this paper, one needs to be able to describe how recent history and social memory become a public affair, how 
does "memory matter" (Brown, 2008; Campbell, 2008). A critical-interpretive perspective suggests that creating a national memory of communism should perhaps no longer start with accepting the meaning of communism as "readymade and meaningful beyond all question" (Schütz, 1967). This position should not be seen as denying the significance and overall social value of the ways in which historians, political scientists, sociologists, approach the issue of coming to terms with the recent communist past. Historical knowledge of the objective (ideological) makeup of political regimes and other social formations should be continually sought as a remedy for half-truths, political manipulation or simply ignorance. Yet, such knowledge, used and reproduced as a "matter of fact", is arguably inadequate with regard to the handling of dilemmas and ambiguities of social memory or to the development of broader social scientific frameworks of analysis. One needs to strive to find the meaning of the social memory of communism in the sometimes contradictory, paradoxical attitudes and meanings that members of society upheld and negotiate, and not only in the official representations of recent history "compressed into generalities" (Veyne, 1984: 63). One should reveal idiographic as well as nomothetic aspects of social memory. The study of social memory and coming to terms with the past in post-communist societies must engage with the dialogue between factual truth and diversity of opinions, individual/subjective and official remembrances. Not all members of a national community will tell the same stories. A community of memory (and agreement/consensus) around the representation of recent history cannot be constructed and rendered meaningful if it is does not originate on a "shared memory", one that can "integrate" and "calibrate" (Margalit, 2002) different 
perspectives and stances.

\section{References}

Adorno, T. W. 1986. What Does Coming to Terms with the Past Mean? In G. Hartman (Ed.), Bitburg in Moral and Political Perspective. Bloomington: Indiana University Press, pp. 114-129.

Andrews, M. 2003. Grand National Narratives and the Project of Truth Commissions: A Comparative Analysis. Media, Culture \& Society, 25, 45-65.

Andrews, M. 2007. Shaping History: Narratives of Political Change. Cambridge: Cambridge University Press.

Antohi, S., \& Tismăneanu, V. (Eds.) 2000. Between Past and Future: The Revolutions of 1989 and their Aftermath. Budapest: CEU

Arendt, H. 1977. Between Past and Future: Eight Exercises in Political Thought. New York: Penguin.

Badescu, G., Comsa, M., Gheorghita, A., Stanus, C. \& Tufis, C. (2010) Implicarea civica si politica a tinerilor (Fundatia Soros Romania). Constanta: Editura Dobrogea.

Billig, M. 1995. Banal Nationalism. London: Sage.

Billig, M. 1996. Arguing and Thinking ( $2^{\text {nd }}$ ed). Cambridge: Cambridge University Press.

Billig, M., Condor, S., Edwards, D., Gane, M., Middleton, D., \& Radley, A. 
(1988) Ideological Dilemmas: A Social Psychology of Everyday Thinking. London: Sage.

Bodnar, J. 1992. Remaking America: Public Memory, Commemoration, and Patriotism in the Twentieth Century. Princeton, NJ: Princeton University Press.

Boym, S. 2001. The Future of Nostalgia. New York: Basic Books

Brockmeier, J. 2010. After the Archive. Remapping Memory. Culture \& Psychology, 16, 5-35.

Brown, S.D. 2008. The Quotation Marks Have a Certain Importance: Prospects for a "Memory Studies". Memory Studies, 1, 261-271. Bucur, M. 2009. Heroes and Victims: Remembering War in TwentiethCentury Romania. Bloomington: Indiana University Press.

Campbell, S. 2008. The Second Voice. Memory Studies, 1, 41-48.

Carr, D. 2008. The Reality of History. In Rüsen, J. (Ed.), Meaning and Representation in History. New York: Berghahn Books, pp. 123-136.

Chesneaux, J. 1978. Past and Futures or What is History For. Thames \& Hudson Ltd.

Chua, B. 1979. Democracy as Textual Accomplishment. Sociological Quarterly, 20, 541-549.

Cesereanu, R. 2008. The Final Report on the Holocaust and the Final Report on the Communist Dictatorship in Romania. East European Politics and Societies, 22, 270-281.

Ciobanu, M. 2009. Criminalising the Past and Reconstructing Collective Memory: The Romanian Truth Commission. Europe-Asia Studies, 61, 313-336. 
Cohen, S. 2006. History Out of Joint: Essays on the Use and Abuse of History. Baltimore: The John Hopkins University Press.

Connolly, W. 1993. The Terms of Political Discourse ( $3^{\text {rd }}$ ed). Oxford: WileyBlackwell.

Dâncu, V. S. 2010. Nimic nu e mai imprevizibil decit trecutul [Nothing is more unpredictable than the past]. Available at http://www.ires.com.ro/articol/93/romanii--i-nostalgia-comunismului [accessed January 2011]

Edelman, M. 1970. The Symbolic Uses of Politics. University of Illinois Press.

Edelman, M. 2001. The Politics of Misinformation. Cambridge: Cambridge University Press.

Ekman, J., \& Linde, J. 2005. Communist Nostalgia and the Consolidation of Democracy in Central and Eastern Europe. Journal of Communist Studies and Transition Politics, 21, 354-374.

Ernu, V., Rogozanu, C., Siulea, C., \& Tichindeleanu, O. (2008) Iluzia anticomunismului: Lecturi critice ale Raportului Tismaneanu [The illusion of anticommunism: critical readings of Tismaneanu Report]. Chisinau: Editura Cartier.

Knights, M. this issue. Taking a Historical Turn: Possible Points of Connection between Social Psychology and History. Integrative Psychological and Behavioral Science. * *

Fine, G. 2001. Difficult Reputations: Collective Memories of the Evil, Inept and Controversial. Chicago: University of Chicago Press.

Fitzpatrick, S. 2000. Everyday Stalinism: Ordinary Life in Extraordinary Times. Oxford: Oxford University Press. 
Freud, S. 1937. Analysis Terminable and Interminable. SE, 23, 209-253.

Friedlander, S. 1992. Introduction. In S. Friedlander (Ed.), Probing the Limits of Representation: Nazism and the "Final Solution". Cambridge, MA: Harvard University Press, pp. 1-21.

Galasińska, A., \& Galasiński, D. (Eds.) 2010. The Post-Communist Condition: Public and Private Discourses of Transformation. Amsterdam: John Benjamins

Gallinat, A. 2009. Intense Paradoxes of Memory: Researching Moral Questions about Remembering the Socialist Past. History \& Anthropology, 20, 183-199.

George, A. 2011. Intre Documente, Amintiri, Trairi [Documents, Recollections, Feelings], Revista 22, 22-28 February, 10.

Gergen, K. 2005. Narrative, Moral Identity and Historical Consciousness: A Social Constructionist Account. In J. Sträub (Ed.), Narration, Identity and Historical Consciousness. New York: Bergham Books, pp. 99-119.

Habermas, J. 1995. Reconciliation through the public use of reason: Remarks on John Rawls's political liberalism. The Journal of Philosophy, 92, 109131.

Halbwachs, M. 1992. On Collective Memory. Chicago: Chicago University Press.

Hogea, A. 2010. Coming to Terms with the Communist Past in Romania: An Analysis of the Political and Media Discourse Concerning the Tismăneanu Report. Studies of Transition States and Societies, 2, 1630.

lacob, B.C. 2010. "Avem Nevoie de o Pedagogie a Memoriei Colective a 
Trecutului Comunist" [We Need a Pedagogy of the Collective Memory of the Communist Past]. Available at http://www.evz.ro/detalii/stiri/bogdancristian-iacob-avem-nevoie-de-o-pedagogie-a-memoriei-colective-atrecutului-comunist-90689.html [accessed January 2011] Jay, M. 1992. Of Plots, Witnesses and Judgments. In S. Friedlander (Ed.), Probing the Limits of Representation: Nazism and the "Final Solution". Cambridge, MA: Harvard University Press, pp. 97-107.

Jenkins, J. 1991. Re-thinking History. London: Routledge.

Jovchelovitch, S. this issue. [Insert final title]. Integrative Psychological and Behavioral Science. * ${ }^{*}$

Kansteiner, W. 2002. Finding Meaning in Memory: A Methodological Critique of Collective Memory Studies. History \& Theory, 41, 179-197.

Kattago, S. (2009) Agreeing to disagree on the legacies of recent history: memory, pluralism, and Europe after 1989. European Journal of Social Theory, 12, 375-395.

LaCapra, D. 2001. Writing History, Writing Trauma. Baltimore, MD: Johns Hopkins University Press.

Liu, J. H., \& Hilton, D. J. 2005. How the Past Weighs on the Present: Social Representations of History and their Role in Identity Politics. British Journal of Social Psychology, 44, 537-556.

Lowenthal, D. 1989. Nostalgia Tells it Like it Wasn't. In C. Shaw \& M. Chase (Eds.), The Imagined Past: History and Nostalgia. Manchester and New York: Manchester University Press.

Marková, I. 1997. Individual and Community: Post-communist Perspective in Change. Community and Applied Social Psychology, 7, 1-102. 
Marková, I. (Ed.) 2004. Trust and Democratic Transition in Post-Communist Europe. British Academy/Oxford University Press.

Marková, I., Moodie, E., Farr, R., Drozda-Senkowska, E., Erös., Plichtová, J., Gervais, Marie-Claude., Hoffmannová, J., \& Mullerová, O. 1998. Social Representations of the Individual: A Post-Communist Perspective.

European Journal of Social Psychology, 28, 797-829.

Margalit, A. 2002. The Ethics of Memory. Harvard University Press

Middleton, D., \& Brown, S. D. 2005. The Social Psychology of Experience:

Studies in Remembering and Forgetting. London: Sage.

Middleton, D., \& Brown, S. D. 2007. Issues in the Socio-Cultural Study of Memory: Making Memory Matter. In J. Valsiner \& A. Rosa (Eds.), The Cambridge Handbook of Sociocultural Psychology. Cambridge:

Cambridge University Press, pp. 661-677.

Millstone, N. (this issue) Historicizing Common Sense. Integrative Psychological and Behavioral Science. * .

Moscovici, S. 2007. Psychoanalysis: Its Image and Its Public. Polity Press Nietzsche, F.W. 1980. On the Advantage and Disadvantage of History for Life (translated by Peter Preuss). Hackett Publishing Co, Inc.

Olick, J. 2007. The Politics of Regret: On Collective Memory and Historical Responsibility. London: Routledge.

Pennebaker, J., Paez, D., \& Rime, B. (Eds.) 1997. Collective Memory of Political Events: Social Psychological Perspectives. Mahwah, NJ: Lawrence Erlbaum.

Petrescu, C. \& Petrescu, D. 2007. Mastering vs. Coming to Terms with the Past: A Critical Analysis of Post-Communist Romanian Historiography. 
In Antohi, A., Trencsenyi, B., \& Apor, P. (Eds.), Narratives Unbound: Historical Studies in Post-Communist Europe. Budapest: CEU Press, pp. $311-408$.

Pickering, M., \& Keightley, E. 2006. The Modalities of Nostalgia. Current Sociology, 54, 919-941.

Poole, R. 2008. Memory, History and the Claims of the Past, Memory Studies, $1,149-166$.

Potter, J., \& Wetherell, M. (1987) Discourse and Social Psychology: Beyond Attitudes and Behaviour. London: Sage

Pridham, G. 2000. Confining Conditions and Breaking with the Past: Historical Legacies and Political Learning in Transitions to Democracy. Democratization, 7, 36-64.

Radstone, S. 2010. Nostalgia: Home-comings and Departures. Memory Studies, 3, 187-191.

Rowe, S., Wertsch, J., \& Kosyaeva, T. 2002. Linking Little Narratives to Big Ones: Narrative and Public Memory in History Museums. Culture \& Psychology, 8, 96-112.

Schütz, A. 1964. Collected Papers II: Studies in Social Theory (edited and introduced by A. Brodersen). The Hague, The Netherlands: Martinus Nijhoff Publishers.

Schütz, A. 1967. Collected Papers I: The Problem of Social Reality (edited by M.A. Natanson and H.L. van Breda). Dordrecht, The Netherlands: Martinus Nijhoff Publishers.

Schütz, A. 1970. On Phenomenology and Social Relations (edited by H.R. Wagner). Chicago: University of Chicago Press. 
Schütz, A. 1975. Collected Papers III. Studies in Phenomenological Philosophy (edited by I. Schutz, Aron Gurwitsch). Dordrecht, The Netherlands: Martinus Nijhoff Publishers.

Skinner, Q. 2002. Visions of Politics: Regarding Method (Volume I).

Cambridge: Cambridge University Press.

Smith, D. 1974. The Social Construction of Documentary Reality. Sociological Inquiry, 44, 257-268.

Stan, L. 2006. The Vanishing Truth: Politics and Memory in Post-Communist Europe. East European Quarterly, 40, 383-408.

Stan, L. 2007 Comisia Tismăneanu: Repere Internationale [The Tismăneanu Commission: International Landmarks]. Sfera Politicii, 126-127, 7-13.

Sztompka, P. 2004. The Trauma of Social Change: A Case of Postcommunist Societies. In J. C. Alexander, R. Eyerman, B. Giesen, N. J. Smelser, and P. Sztompka (Eds.), Cultural Trauma and Collective Identity. Berkeley: University of California Press, pp. 155-195.

Tapalagă, D. 2011. 'Cine au fost securistii, frate?'. Available at http://www.hotnews.ro/stiri-11017431-audio-cine-fost-securistii-frate.htm (accessed January 2012)

Tateo, L. \& Iannaccone, A. 2012. Social Representations, Individual and Collective Mind: A Study of Wundt, Cattaneo and Moscovici. Integrative Psychological and Behavioral Science, 46, 57-69.

Taylor, C. 2004. Modern Social Imaginaries. Durham and London: Duke University Press.

Teitel, R. 2000. Transitional Justice. Oxford: Oxford University Press.

Thompson, J. 2009. Apology, Historical Obligations and the Ethics of Memory. 
Memory Studies, 2, 195-210.

Tileagă, C. 2009. The Social Organization of Representations of History: The Textual Accomplishment of Coming to Terms with the Past. British Journal of Social Psychology, 48, 337-355.

Tileagă, C. 2011. Rewriting biography: memory, identity and textuallymediated reality in coming to terms with the past. Culture and Psychology, 17, 197-215.

Tileagă, C. in press, a. Communism in retrospect: the rhetoric of historical representation and writing the collective memory of recent past. Memory Studies. * *

Tileagă, C. in press, b. The right measure of guilt: moral reasoning, transgression and the social construction of moral meanings. Discourse and Communication. * *

Tismăneanu, V. 2007a. Confronting Romania's Past: A Response to Charles King. Slavic Review, 66, 724-727.

Tismăneanu, V. 2007b. Refuzul de a Uita. Articole şi Comentarii Politice (2006-2007) [The refusal to forget. Articles and political commentaries (2006-2007). lasi: Curtea Veche

Tismăneanu, V. 2008. Democracy and Memory: Romania Confronts its Communist Past. Annals of the American Academy of Political and Social Science, 617, 166-180.

Tismăneanu, V. 2010a. Despre Nostalgia Comunismului, Peronism si Spaima de Libertate [On Nostalgia for Communism, Peronism and Escape from Freedom]. Available at http://tismaneanu.wordpress.com/2010/12/15/despre-nostalgia- 
comunismului-peronism-si-spaima-de-libertate/ [accessed January 2011] Tismăneanu, V. 2010b. Plang Romanii Dupa Comunism? Amintirea Dictaturii si Anxietatile Prezentului [Are Romanians Regretting Communism? Remembering Dictatorship and the Anxieties of the Present]. Available at http://tismaneanu.wordpress.com/2010/09/23/amintireacomunismului-si-anxietatile-prezentului/ [accessed January 2011] Tismăneanu, V. 2010c. Citizenship restored. Journal of Democracy, 21, 128135.

Tismăneanu, V., Dobrincu, D. \& Vasile, C. (Eds.) 2007. Raport Final: Comisia Prezidentiala pentru Analiza Dictaturii Comuniste din Romania [Final Report: The Presidential Commission for the Analysis of the Communist Dictatorship in Romania]. Bucharest: Humanitas.

Todorov, T. 2009. In Defence of the Enlightenment. London: Atlantic Books Todorova, M., \& Gille, S. (Eds.) 2010. Post-Communist Nostalgia. Berghahn Books.

Velikonja, M. 2009. Lost in Transition: Nostalgia for Socialism in Post-Socialist Countries. East European Politics and Societies, 23, 535-551.

Veyne, P. 1984. Writing History: Essay on Epistemology (translated by Mina Moore-Rinvolucri). Middletown, Connecticut: Wesleyan University Press. Waskiewicz, A. 2010. The Polish Home Army and the Politics of Memory.

East European Politics and Society, 24, 44-58.

Watson, R. 2009. Analyzing Practical and Professional Texts: A Naturalistic Approach. Ashgate Wertsch, J. 2002. Voices of Collective Remembering. Cambridge: Cambridge University Press. 
Wertsch, J. 2007. Collective Memory. In J. Valsiner \& A. Rosa (Eds.) The Cambridge Handbook of Sociocultural Psychology. Cambridge: Cambridge University Press, pp. 645-660.

Wertsch, J. 2008. Collective Memory and Narrative Templates, Social Research, 75, 133-156.

Wertsch, J. 2011. Beyond the Archival Model of Memory and the Affordances and Constraints of Narratives. Culture \& Psychology, 17, 21-29.

Wertsch, J. \& Karumidze, Z. 2009. Spinning the Past: Russian and Georgian Accounts of the War of August 2008. Memory Studies, 2, 377-391.

Willinger, I. (Ed.) 2007. N/Osztalgia - Ways of Revisiting the Socialist Past. Budapest, Hungary: Anthropolis 